Terbit online pada laman web jurnal : http://teknosi.fti.unand.ac.id/

Jurnal Nasional Teknologi dan Sistem Informasi

| ISSN (Print) 2460-3465 |ISSN (Online) 2476-8812|

Studi Kasus

\title{
Sistem Monitoring Kendaraan Secara Real Time Berbasis Android menggunakan Teknologi CouchDB di PT. Pura Barutama
}

\author{
Ramos Somya ${ }^{a}$ \\ a Program Studi S1 Teknik Informatika Universitas Kristen Satya Wacana, Jl. Diponegoro 52-60 Salatiga, Jawa Tengah, Indonesia
}

\begin{tabular}{l} 
INFORMASI ARTIKEL \\
\hline Sejarah Artikel: \\
Diterima Redaksi: 05 Februari 2018 \\
Revisi Akhir: 28 Juli 2018 \\
Diterbitkan Online: 31 Agustus 2018 \\
KATA KUNCI \\
\hline Sistem Monitoring Kendaraan, \\
CouchDB, \\
GPS \\
KORESPONDENSI \\
\hline Telepon: +62 85640326685 \\
E-mail: mailto:ramos.somya@staff.uksw.edu \\
\hline
\end{tabular}

\section{A B S T R A C T}

PT. Pura Barutama is a company with many production areas. Products that have been produced will be delivered to some destinations using company's vehicles. Those vehicles are managed by Vehicle Unit of PT. Pura Barutama. Based on the research, there is a problem in the term of vehicle tracking and monitoring. The delay of product delivery is often occur for no apparent reason from the drivers. Previously, Vehicle Unit already has a GPS Tracker installed on each vehicle, but this GPS Tracker can only be triggered using SMS to send the location of vehichles. This method causes the lack of tracking and monitoring information obtained by the company. This research developed a new model of tracking and monitoring system based on Android platform. CouchDB technology is also used to provide a real time tracking and monitoring system. The test result shows that this new system has advantages compared with the old tracking system and can be used to replace the old system.

\section{PENDAHULUAN}

PT. Pura Barutama Kudus memiliki banyak bidang produksi [1]. Barang-barang hasil produksi kemudian akan dikirimkan ke masing-masing customer. Unit Kendaraan adalah unit yang bertanggung jawab untuk semua pengiriman barang hasil produksi. Kendaraan yang dipakai terdiri dari kendaraan milik Unit Kendaraan sendiri dan kendaraan sewa dari pihak ketiga.

Selama ini proses pengiriman oleh Unit Kendaraan dimulai dari request dari masing-masing unit produksi. Saat satu unit produksi melakukan request pengiriman, maka unit kendaraan akan mengeluarkan sebuah Surat Pengiriman (SP) yang berisi informasi untuk pengiriman barang, di antaranya: rincian barang kiriman, waktu pengiriman, alamat tujuan pengiriman, dan nomor plat kendaraan yang dipakai.Surat pengiriman akan diberikan kepada driver kendaraan, sendangkan unit produksi akan diberikan nomor dari surat pengiriman yang merupakan nomor SP barang milik unit produksi yang bersangkutan.Kemudian setelah kapasitas dari satu kendaraan sudah terpenuhi (bisa terdiri dari beberapa SP) maka kendaraan akan berangkat dengan membawa satu nomor Delivery Order (DO). Saat barang sudah sampai ke customer, maka customer akan memberikan tanda tangan pada surat pengiriman (SP) sebagai bukti/verifikasi bahwa barang sudah sampai di tujuan. SP yang sudah diverifikasi kemudian akan dipakai oleh unit produksi untuk membuat faktur tagihan.

Selama proses pengiriman, unit produksi dapat memeriksa sampai mana proses pengiriman barang dengan bertanya kepada unit kendaraan menggunakan nomor SP. Banyaknya barang yang dikirimkan menyebabkan proses pengecekan barang kiriman dengan bertanya ke unit kendaraan menjadi lebih sulit. Keadaan ini bertambah sulit karena sistem GPS tracker yang dipakai adalah GPS pasif yang memerlukan trigger dengan cara mengirimkan SMS ke perangkat GPS untuk mendapatkan data lokasi kendaraan. Berdasarkan masalah yang telah dijelaskan, maka latar belakang dari penelitian ini adalah membuat sistem monitoring kendaraan secara real time yang dapat diakses langsung oleh masing-masing unit produksi tanpa meminta informasi kepada unit kendaraan. Teknologi real time memungkinkan untuk membuat suatu sistem monitoring dengan jeda waktu yang minimal. Informasi lokasi kendaraan akan langsung diketahui di saat yang bersamaan dengan bergeraknya kendaraan. Teknologi ini kemudian dapat digabungkan dengan perangkat Android sehingga dapat diakses secara mobile oleh siapa saja, di mana saja, dan kapan saja. Maka solusi yang diberikan untuk masalah yang ada adalah dengan membuat sistem

Attribution-NonCommercial 4.0 International. Some rights reserved 
monitoring kendaraan berbasis Android yang berfungsi untuk memantau lokasi kendaraan secara real time.

Berdasarkan latar belakang yang telah dijelaskan, didapatkan rumusan masalah yaitu bagaimana membuat sistem monitoring yang dapat memberikan laporan data lokasi kendaraan secara real time dan dapat diakses dengan cepat dan akurat saat dibutuhkan. Penelitian ini terfokus pada pembuatan prototype sistem tracking, sehingga penelitian ini memiliki batasan-batasan dalam pembahasannya. Batasan tersebut di antaranya, sistem tracking akan dibuat pada perangkat Android dengan GPS terintegrasi, sistem dibangun menggunakan Android native programming (Java) dengan real time database Apache CouchDB, sistem yang dibuat memerlukan versi minimal API Android 19, sistem tracking menggunakan proses bisnis pengiriman barang yang sudah ada di Unit Kendaraan PT. Pura Barutama.

\section{TINJAUAN PUSTAKA}

\subsection{Penelitian Sebelumnya}

Terdapat beberapa penelitian yang telah dilakukan sebelumnya mengenai sistem tracking menggunakan perangkat Android, salah satunya adalah penelitian yang dilakukan oleh Wahyu Kusuma dan Tity Septiani dengan judul "Aplikasi Friend Tracker berbasis Android Smartphone menggunakan GPS Tracking”. Penelitian ini membahas tentang implementasi GPS Tracking yang digunakan dalam aplikasi pencarian lokasi teman. Hasil akhir dari penelitian ini yaitu sebuah sistem tracking menggunakan perangkat Android yang berfungsi untuk mengetahui posisi teman yang telah terdaftar dalam friend list [2].

Penelitian yang kedua dilakukan oleh Muhammad Dzani Alfikridengan judul "Aplikasi Auto-Reporting Position Tracking Berbasis Android Untuk Mengetahui Posisi Device Sebagai Sarana Monitoring Posisi Karyawan di PT Telkom Indonesia Kota Malang". Penelitian ini menghasilkan satu aplikasi berbasis Android yang digunakan untuk memantau lokasi setiap karyawan PT. Telkom Indonesia di kota Malang dengan tujuan meningkatkan produktifitas kerja para karyawan [3].

Perbandingan penelitian ini dengan dua penelitian sebelumnya adalah penggunaan teknologi real time pada sistem tracking. Aplikasi pada penelitian pertama hanya memberikan data lokasi terakhir saat pengguna melakukan sign-up ataupun melakukan update lokasi dalam profilnya. Sedangkan sistem tracking pada penelitian kedua menggunakan interval waktu dalam mengirimkan data lokasi setiap karyawan ke database SQL. Pelaporan data lokasi secara real time dalam penelitian ini dimungkinkan dengan menggunakan real time database.

\subsection{Real-Time Database System}

Real time database adalah database yang menggunakan real time processing untuk menangani data yang nilainya terus berubah, tidak seperti database tradisional yang menyimpan data tetap/persistent [4]. Real time database juga disebut dengan NOSqldatabase, di mana SQL database adalah sebutan untuk relational database. NOSql (Not Only Sql) memiliki kelebihan yang tidak dimiliki oleh SQL database. NOSqldatabase tidak terikat dengan skema (schema-free), mendukung replikasi dengan mudah, memiliki API yang lebih sederhana, dan mampu menangani data yang sangat besar (big data) [5]. CouchDB adalah salah satu contoh dari real time database system (RTDBS) yang dikembangkan oleh Apache. CouchDB tidak menggunakan tabel (baris dan kolom) untuk menyimpan data, melainkan menggunakan struktur file JSON (key-value pair). Sebuah record dalam CouchDB disebut juga satu dokumen (document). Satu dokumen merupakan satu file berformat JSON yang memiliki ID (primary key), REV (revision id), dan isi data yang disimpan. ID digunakan sebagai unique identifier yang membedakan dokumen satu dengan yang lainnya. Sedangkan revision id digunakan untuk menjaga konsistensi data [6].

\subsection{CouchDB}

CouchDB memiliki API berbasis HTTP REST yang memudahkan client untuk mengakses database. Maka dalam mengakses CouchDB, client dapat menggunakan perintah seperti PUT, GET, dan DELETE yang ada pada HTTP [7]. LightCouch adalah library Java yang berfungsi sebagai antarmuka (interface) untuk berkomunikasi dengan CouchDB menggunakan HTTP. API dalam LightCouch diakses dengan membuat koneksi dari client ke server CouchDB. Client adalah objek utama yang melakukan setiap request ke database, dalam konteks ini adalah request dokument ataupun view. API LightCouch berfokus dalam CRUD dokumen, view, attachment, design documents, changes notification, dan operasi database CouchDB yang spesifik seperti compaction dan replication [8].

\subsection{Google Maps}

Google Maps adalah salah satu layanan yang disediakan oleh Google. Google Maps memiliki keunggulan dalam hal kelengkapan dan detail peta. Hal ini disebabkan karena Google Maps mengijinkan pengguna untuk berkontribusi dalam pengembangan peta [9]. Google Maps juga dapat diakses dari berbagai platform, salah satunya dari platform Android menggunakan Google Maps Android API [10]. API ini memungkinkan pengembang untuk mengintegrasikan Google Maps pada sistem yang dibuat.

\section{METODE DAN PERANCANGAN SISTEM}

Penelitian ini dilakukan dengan 5 tahapan penelitian yaitu: (1) analisis kebutuhan dan pengumpulan data; (2) perancangan sistem; (3) perancangan aplikasi; (4) implementasi dan pengujian sistem dengan cara simulasi; dan (5) penulisan laporan hasil penelitian [11]. Tahapan yang dilakukan dalam penelitian ini dapat dilihat pada Gambar 1.

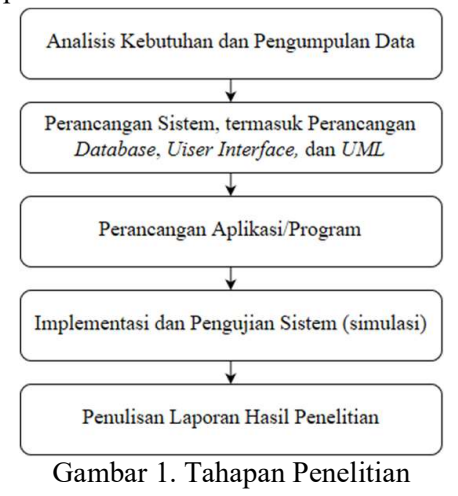

https://doi.org/10.25077/ TEKNOSI.v4i2.2018.053-060 
Berdasarkan bagan pada Gambar 1 dapat dijelaskan bahwa tahapan penelitian yang dilakukan adalah: Tahap pertama analisis kebutuhan dan pengumpulan data, di mana pihak pengembang mencari informasi mengenai kebutuhan dari pengguna yang berhubungan dengan pembuatan sistem. Pencarian informasi dilakukan dengan cara wawancara secara langsung kepada pihak MIS (Management and Information System) PT. Pura Barutama. Berdasarkan hasil dari wawancara yang dilakukan didapatkan informasi bahwapihak unit kendaraan sudah memiliki sistem monitoring yang dibuat menggunakan GPS tracker berbasis SMS. Sistem monitoring kendaraan ini dianggap tidak praktis oleh unit produksi. Hal ini disebabkan karena unit produksi harus bertanya kepada unit kendaraan untuk meminta informasi lokasi kendaraan. Pihak MIS kemudian mencari cara untuk membantu menyelesaikan masalah tersebut. Pada tahap kedua, ketiga dan keempat dilakukan perancangan sistem monitoring kendaraanmenggunakan metode pengembangan sistem Prototype. Tahap kelima dilakukan penulisan laporan ilmiah dan artikel ilmiah.

Perancangan dan pembuatan aplikasi dalam penelitian ini dilakukan menggunakan metode Prototype. Metode ini menggunakan sebuah siklus dalam menghasilkan suatu produk. Produk yang dihasilkan dari metode prototype akan diuji, jika terdapat kekurangan maka akan dilakukan siklus prototype kembali untuk memperbaiki produk sebelumnya.

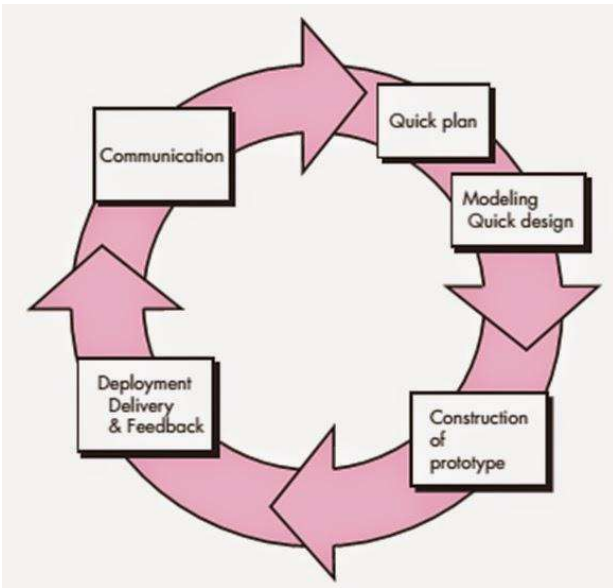

Gambar 2. Metode Prototype [12]

Seperti yang digambarkan pada Gambar 2, metode Prototype dimulai dengan communication yaitu analisis kebutuhan sistem yang akan dibuat. Analisa ini dapat diperoleh dari pengumpulan data, baik bersumber dari literatur maupun penelitian sebelumnya.

Langkah selanjutnya adalah planning dan design, di mana software akan dibuat rancangannya secara garis besar. Perancangan / design software ini meliputi bagaimana program akan berjalan, meliputi semua aspek software yang diketahui. Pembuatan desain program dapat dilakukan dengan atau tanpa software bantuan (seperti software UML). Pada tahap analisis sebelumnya telah diperoleh system requirement yang didapat dari pengumpulan data. Tentunya pada tahap perancangan/design, requirement pada tahap sebelumnya harus dipertimbangkan dengan matang untuk fitur apa saja yang memungkinkan untuk dibuat. Setelah dilakukan planning dan design, maka selanjutnya sistem akan masuk dalam tahap construction atau pembuatan.

https://doi.org/10.25077/ TEKNOSI.v4i2.2018.053-060
Desain akan diubah menjadi bahasa pemrograman yang dapat dijalankan oleh platform tujuan. Programmer akan menerjemahkan kebutuhan sistem yang didapat dari tahap-tahap sebelumnya. Pembuatan sistem tracking dalam penelitian ini menggunakan bahasa Java yang merupakan bahasa native dalam pemrograman aplikasi berbasis Android menggunakan Android Studio. Setelah sistem selesai diterjemahkan ke dalam bahasa pemrograman, semua fungsi sistem harus diuji coba agar dapat dinilai apakah sistem sudah siap untuk dipakai atau belum. Pengujian sistem yang dibuat dilakukan dengan blackbox testing [13]. Saat sistem sudah lulus tahap testing maka sistem sudah siap untuk masuk ke tahap deployment, namun jika masih terdapat kekurangan makaakan dikembangkan lebih lanjut dengan mengulangi siklus prototyping.

Tahap terakhir dari penelitian adalah analisis dan pengambilan kesimpulan. Analisis dilakukan untuk menilai apakah algoritma dan metode yang dipakai dalam pengenalan real time tracking sudah baik atau sebaliknya, dan faktor-faktor apa saja yang mempengaruhi performa software.

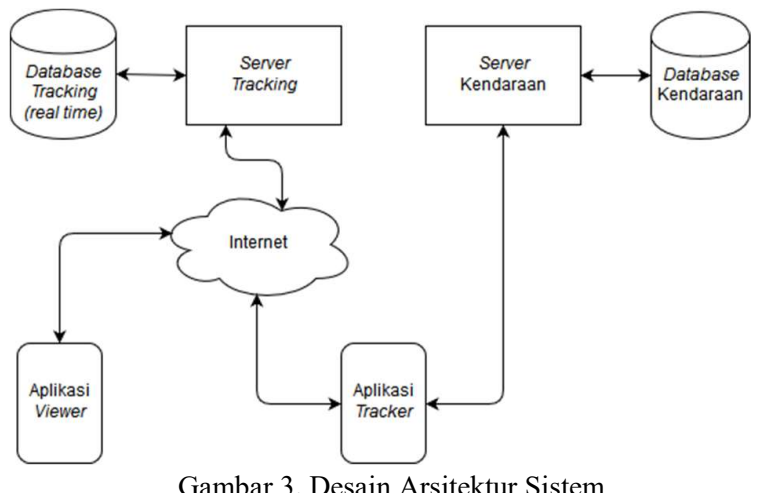

Gambar 3. Desain Arsitektur Sistem

Gambar 3 menjelaskan desain arsitektur sistem yang dibuat. Sistem monitoring dirancang untuk menggunakan 1 server dengan IP publik yang digunakan sebagai serverreal time database CouchDB, 1 server offline milik unit kendaraan, dan perangkat Android yang terpasang dalam setiap kendaraan. Perangkat Android dalam kendaraan digunakan untuk mengirimkan data lokasi kendaraan ke server real time database saat kendaraan bergerak. Kemudian data yang ada dalam server dapat diakses oleh pengguna aplikasi monitoring (dalam hal ini adalah masing-masing unit produksi). Perancangan sistem dalam penelitian ini dibuat dalam bentuk diagram UML. Diagram UML meliputi usecase diagram dan class diagram.

Gambar 4 merupakan use case yang menjelaskan bagaimana sistem monitoring kendaraan dibuat. Sistem memiliki 2 aktor, yaitu administrator yang memiliki hak akses penuh ke dalam sistem, termasuk mengelola data kendaraan, mengelola laporan kendaraan, dan mengelola data laporan akhir (final report) setiap kendaraan. Aktor yang kedua adalahdriveryang memiliki hak akses untuk melakukan login ke dalam sistem tracking dan melaporkan status kendaraan (termasuk melakukan verifikasi pengiriman barang).

Evaluasi Prototype sistem monitoring kendaraan dievaluasi dengan dua cara. Cara yang pertama adalah dengan melakukan uji lapangan secara langsung. Uji lapangan melibatkan staff MIS 
dan pengembang sistem untuk menguji sistem tracking dengan cara membawa aplikasi tracker dan melakukan kegiatan seharihari. Evaluasi ini dilakukan dengan maksud menguji stabilitas algoritma tracking pada aplikasi tracker. Hal ini diperlukan mengingat aplikasi tracker harus berjalan selama berhari-hari tanpa mengalami error/crash dengan mempertimbangkan semua keadaan seperti tidak adanya koneksi internet di beberapa tempat. Evaluasi kedua dilakukan dengan cara simulasi proses bisnis yang dilakukan di unit MIS untuk mencocokkan proses bisnis yang diimplementasi dalam sistem aplikasi trackingdengan proses bisnis yang sudah ada sebelumnya.

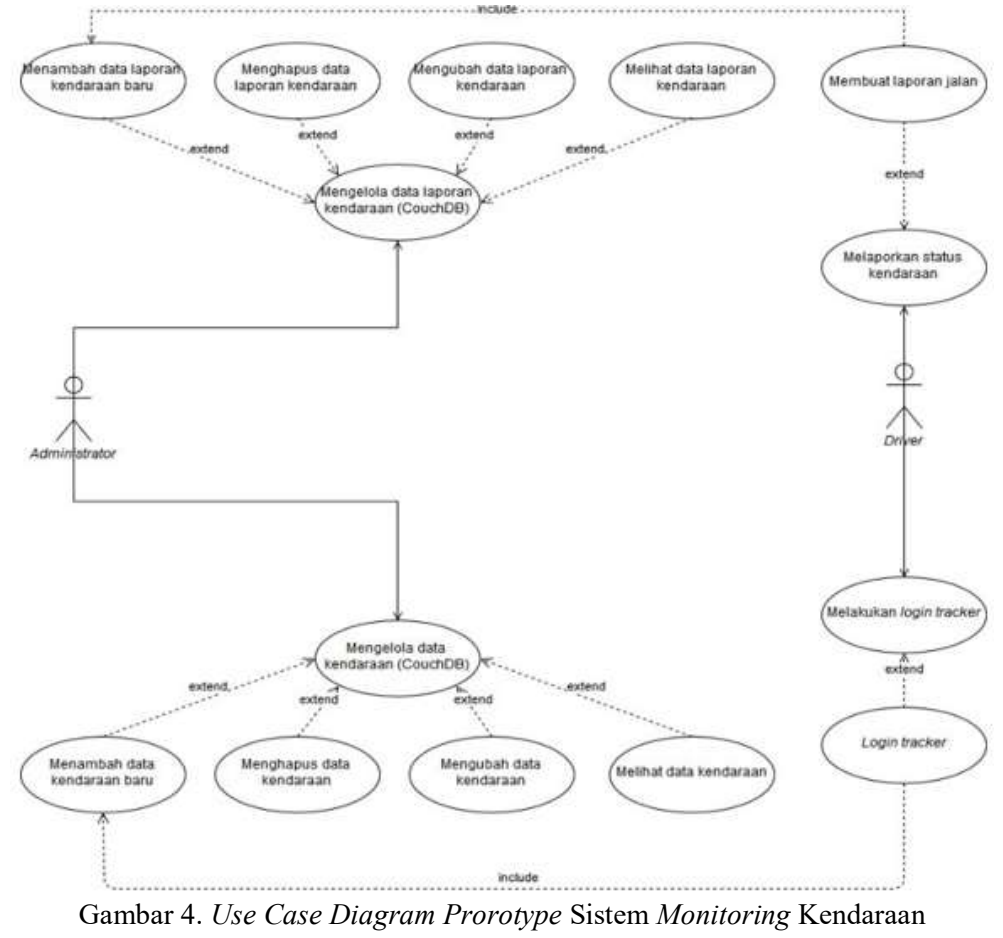

Evaluasi Prototype sistem monitoring kendaraan dievaluasi dengan dua cara. Cara yang pertama adalah dengan melakukan uji lapangan secara langsung. Uji lapangan melibatkan staff MIS dan pengembang sistem untuk menguji sistem tracking dengan cara membawa aplikasi tracker dan melakukan kegiatan seharihari. Evaluasi ini dilakukan dengan maksud menguji stabilitas algoritma tracking pada aplikasi tracker. Hal ini diperlukan mengingat aplikasi tracker harus berjalan selama berhari-hari tanpa mengalami error/crash dengan mempertimbangkan semua keadaan seperti tidak adanya koneksi internet di beberapa tempat. Evaluasi kedua dilakukan dengan cara simulasi proses bisnis yang dilakukan di unit MIS untuk mencocokkan proses bisnis yang diimplementasi dalam sistem aplikasi trackingdengan proses bisnis yang sudah ada sebelumnya.

\section{HASIL DAN PEMBAHASAN}

Sistem monitoring kendaraan dalam penelitian ini terdiri dari 2 aplikasi utama berbasis Android: (1) Aplikasi sisi driver (tracker) dan (2) Aplikasi sisi administrator (viewer). Aplikasi tracker digunakan oleh driver yang berfungsi sebagai pengganti GPS tracker berbasis SMS pada sistem yang terdahulu dengan tambahan fungsi pelaporan (termasuk pelaporan verifikasi). Sedangkan aplikasi viewer adalah aplikasi yang digunakan oleh administrator untuk melihat posisi setiap kendaraan yang sudah terpasang aplikasi tracker melalui API Google Maps, serta laporan live dari setiap driver kendaraan.

Garis besar proses bisnis dengan sistem monitoring yang baru adalah sebagai berikut: (1) Driver menggunakan aplikasi tracker

56 Ramos Somya untuk login dan memulai pengiriman barang. (2) Bila terjadi kendala di perjalanan, driver dapat melaporkan kendala melalui aplikasi tracker. (3) Ketika barang sudah sampai tujuan, driver melakukan verifikasi dengan scan $\mathrm{QR}$ code yang dimiliki customer. (4) Informasi letak kendaraan, laporan driver, dan status verifikasi barang dapat dipantau oleh masing-masing unit produksi menggunakan aplikasi viewer. Aplikasi viewer/sisi administrator juga dapat melakukan override pada proses verifikasi apabila terdapat masalah pada sistem verifikasi dengan QR code oleh aplikasi tracker/sisi driver.
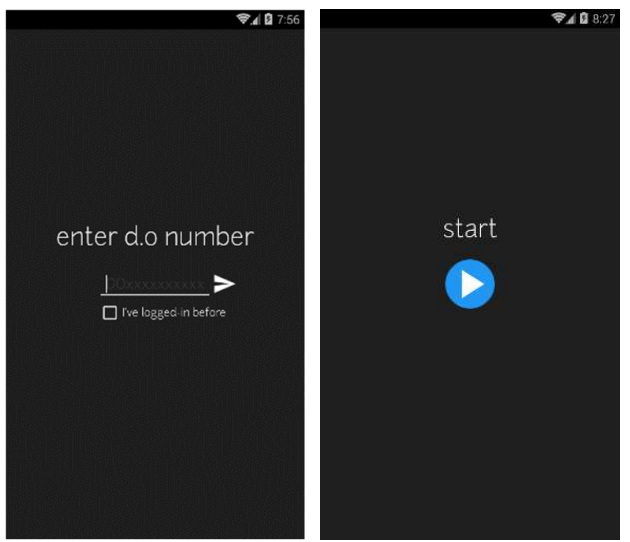

Gambar 5. Halaman Login \& StartAppTracker

Sistem monitoring/tracking kendaraan dimulai saat driver melakukan login melalui aplikasi tracker menggunakan nomor delivery order yang telah diberikan sebelumnya. Untuk melakukan login, smartphone driver harus terkoneksi 
ke jaringan lokal PT. Pura Barutama untuk mencocokkan nomor delivery order yang dimiliki driver, dengan nomor delivery order yang ada di database lokal. Pada halaman login juga disediakan checkbox "I've logged in before", yang berfungsi untuk melakukan login di luar jaringan lokal Pura dengan syarat sudah pernah melakukan login di jaringan lokal. Jika masukan driver valid, maka driver akan dibawa pada halaman start untuk memulai menjalankan sistem tracking. Antarmuka halaman login dan start tracking dapat dilihat pada Gambar 5.

Service sistem monitoring kendaraan akan dijalankan dalam perangkat Android setelah driver menekan tombol start pada layar aplikasi. Mekanisme start service ini melalui beberapa proses: (1) melakukan knocking ke server untuk mendaftarkan IP address perangkat Android, (2) jika IP address perangkat sudah terdaftar maka perangkat diijinkan untuk mengakses port database CouchDB, (3) aplikasi tracker akan membuat koneksi ke database CouchDB, (4) dan yang terakhir service tracking akan dijalankan untuk melaporkan setiap perubahan data lokasi kendaraan yang didapat dari GPS perangkat Android ke database CouchDB.

Mekanisme knocking perlu dilakukan untuk mencegah akses dari pihak yang tidak bertanggung jawab ke database CouchDB. Knocking dilakukan dengan mengakses port tertentu pada host server (yang bersifat rahasia) untuk sekadar mendaftarkan IP address agar mendapat akses untuk mengakses port yang lainnya. Request knocking dilakukan sebelum aplikasi dapat mengakses port CouchDB.

Jika knocking berhasil, maka aplikasi akan mencoba untuk membuat koneksi ke database CouchDB. Koneksi ke dalam CouchDB tidak sama dengan koneksi ke database SQL. Koneksi ke database CouchDB, atau sebagian besar real time database, bersifat persistent atau tetap. Koneksi akan terus terhubung bukan hanya saat melakukan query saja seperti pada database SQL.

Setelah koneksi dibuat, maka aplikasi akan mendaftarkan data kendaraan yang melakukan login ke database CouchDB. Data yang dibuat merupakan data kendaraan dan data laporan kendaran. Data dalam CouchDB akan disimpan dalam bentuk JSON.

Selanjutnya aplikasi tracker akan mengirimkan data latitude dan longitude untuk mengupdate record yang ada pada database CouchDB untuk melakukan tracking. Update data lokasi kendaraan dilakukan dengan cara: (1) aplikasi mengambil nilai latitude dan longitude dengan modul GPS yang terintegrasi pada perangkat Android, (2) mengupdate record pada database dengan menyertakan revision id "_rev" dari record terakhir, (3) jika update maka lakukan proses reconnect ke database CouchDB. Setiap kali suatu record pada CouchDB dilakukan proses update maka atribut_rev akan berubah, sedangkan untuk melakukan update dibutuhkan nilai_rev yang terakhir. Hal ini disebabkan karena adanya proteksi dari CouchDB yang berfungsi untuk menjaga validitas nilai (hanya record terakhir/yang paling baru yang dapat diupdate).
Pengambilan data lokasi kendaran menggunakan classLocationListener yang tersedia dalam Android SDK. Untuk mencapai performa aplikasi yang baik sekaligus penggunaan baterai yang hemat, maka perubahan lokasi hanya akan dicatat ketika perangkat telah bergerak sejauh minimal 200 meter dan 15 detik. Ini menyebabkan perangkat tidak akan mengirimkan posisinya terus-menerus jika hanya berdiam dalam satu tempat yang sama.

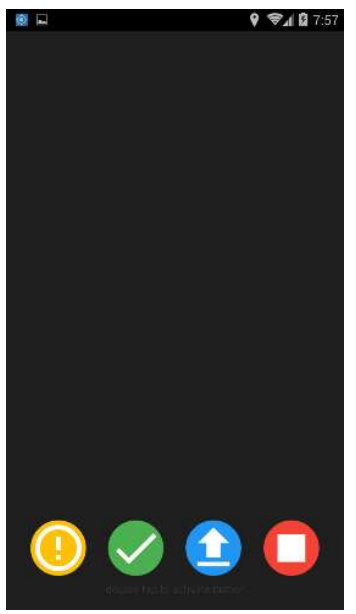

Gambar 6. Halaman Utama Aplikasi Tracker

Fitur tambahan yang ada pada aplikasi tracker adalah adanya fitur pelaporan untuk driver. Fitur ini dibuat untuk menanggulangi kurangnya komunikasi driver kepada unit yang menyebabkan ketidakjelasan jika terjadi delay dalam pengiriman barang. Fitur ini dapat diakses melalui halaman utama aplikasi tracker yang akanmuncul setelah service tracking sudah berjalan. Terdapat 4 menu dalam halaman utama aplikasi tracker yang dapat dilihat pada Gambar 6, menu dari kiri ke kanan adalah: (1) menu report, (2) menu verification, (3) menu final report, dan (4) menu stop tracking service.

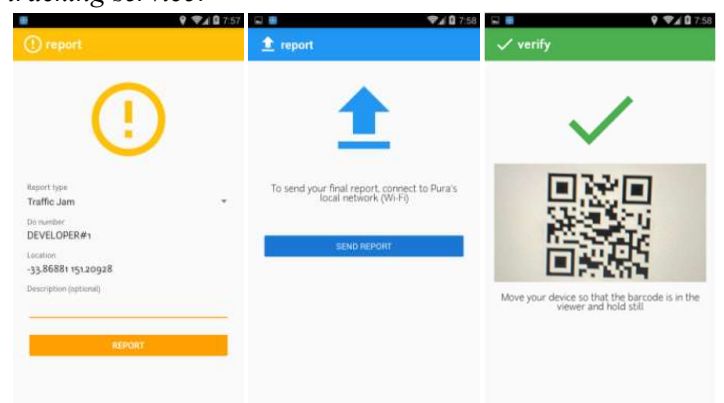

Gambar 7. Halaman Report, Verification, dan Final Report

Menu report (Gambar 7) digunakan untuk melaporkan setiap kejadian yang ada dalam perjalanan. Fitur ini akan menyimpan setiap laporan driver ke dalam database SQLiteinternal Android. Data laporan yang disimpan adalah: jenis laporan, nomor delivery order, waktu kejadian, lokasi, dan keterangan. Data yang disimpan dari fitur report ini akan dilaporkan saat driver sudah sampai di PT. Pura dan digunakan untuk melakukan audit perjalanan yang dilakukan.

Saat driver sudah sampai di tujuan, driver wajib untuk melakukan verifikasi sebagai bukti bahwa customer sudah menerima barang yang dikirim oleh PT. Pura menggunakan menu verification. 
Sebelumnya, customer terlebih dahulu dikirimkan QR Code yang berisi kode verifikasi oleh unit di PT. Pura (fitur ini terdapat dalam aplikasi administrator). Untuk melakukan verifikasi, driver hanya perlu untuk menscan QR Code yang dimiliki customer seperti pada Gambar 7. Data verifikasi ini akan disimpan di SQLite sekaligus ke real time database agar unit dapat mengetahui segera saat driver melakukan verifikasi.

Selanjutnya, menu final report digunakan saat driver sudah kembali ke PT. Pura. Driver wajib untuk "melaporkan" perjalanannya ke sistem. Untuk melaporkan, perangkat Android harus terkoneksi ke jaringan lokal PT. Pura. Semua data perjalanan (history lokasi perjalanan dan laporan/report pada menu pertama) akan dimasukkan ke sistem (Gambar 7).

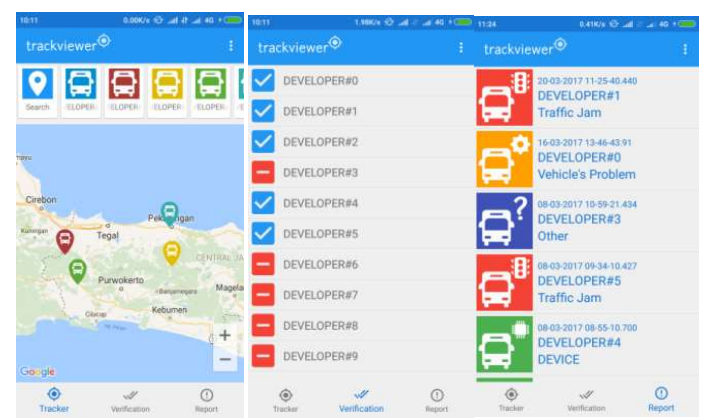

Gambar 8. Tampilan Setiap Menu Aplikasi Viewer
Menu terakhir, sesuai dengan namanya, menu ini akan menghentikan service tracking. Menu ini digunakan saat driver sudah tidak melakukan perjalanan atau saat aplikasi terdapat masalah sehingga membutuhkan restart.

Gambar 8 adalah tampilan dari aplikasi viewer yang digunakan administrator untuk melihat status semua kendaraan yang sedang dalam pengiriman barang. Terdapat 3 menu utama dalam aplikasi viewer: (1) Menu Tracker digunakan untuk melihat lokasi setiap kendaraan dalam peta, (2) Verification digunakan untuk melihat status verifikasi setiap barang yang dikirim, dan (3) Menu report digunakan untuk melihat data laporan yang dibuat driver. Tampilan menu viewer ini memanfaatkan Google Maps, di mana akan menampilkan lokasi aktif dari kendaraan yang dipantau.

Konsep real time yang ditawarkan oleh real time database dapat direalisasikan dengan adanya changes listener pada CouchDB (atau real time database lainnya). Change listener akan memberitahu kepada sistem saat terdapat record yang berubah pada database. Maka saat aplikasi tracker melakukan update terhadap salah satu record kendaraan, aplikasi viewer akan langsung mendapatkan notifikasi dan menampilkannya pada Google Maps. Proses ini lebih sederhana dan tidak memberatkan server dibanding menggunakan database SQL yang harus melakukan long polling untuk select guna mengetahui apakah terdapat record yang berubah pada database.

Tabel 1. Hasil Blackbox Testing

\begin{tabular}{|c|c|c|c|c|}
\hline No & Deskripsi & Hasil yang Diharapkan & $\begin{array}{l}\text { Hasil yang } \\
\text { Diberikan } \\
\text { Sistem }\end{array}$ & $\begin{array}{c}\text { Status } \\
\text { Pengujian }\end{array}$ \\
\hline 1 & $\begin{array}{l}\text { Penguji melakukan login dengan } \\
\text { aplikasi tracker sebagai driver }\end{array}$ & $\begin{array}{c}\text { Aplikasi menerima informasi } \\
\text { login dan berganti ke halaman } \\
\text { start service }\end{array}$ & $\begin{array}{l}\text { Sesuai yang } \\
\text { diharapkan }\end{array}$ & Valid \\
\hline 2 & $\begin{array}{l}\text { Penguji memilih tombol START } \\
\text { pada halaman start service }\end{array}$ & $\begin{array}{l}\text { Aplikasi akan melakukan } \\
\text { serangkaian proses untuk memulai } \\
\text { tracking service, sekaligus } \\
\text { membuat record pada CouchDB }\end{array}$ & $\begin{array}{l}\text { Sesuai yang } \\
\text { diharapkan }\end{array}$ & Valid \\
\hline 3 & $\begin{array}{l}\text { Penguji membuat laporan dari } \\
\text { aplikasi tracker }\end{array}$ & $\begin{array}{c}\text { Laporan terkirim ke database } \\
\text { CouchDB dan tersimpan dalam } \\
\text { SQLite }\end{array}$ & $\begin{array}{l}\text { Sesuai yang } \\
\text { diharapkan }\end{array}$ & Valid \\
\hline 4 & $\begin{array}{c}\text { Penguji melakukan scanQRCode } \\
\text { dalam menu verification pada } \\
\text { aplikasi tracker }\end{array}$ & $\begin{array}{l}\text { QRCode terbaca dan laporan } \\
\text { terkirim ke database CouchDB } \\
\text { dan tersimpan dalam SQLite }\end{array}$ & $\begin{array}{l}\text { Sesuai yang } \\
\text { diharapkan }\end{array}$ & Valid \\
\hline 5 & $\begin{array}{l}\text { Penguji menggunakan menu final } \\
\text { report untuk melaporkan trip log }\end{array}$ & $\begin{array}{l}\text { Log tersimpan dalam database } \\
\text { lokal PT. Pura }\end{array}$ & $\begin{array}{l}\text { Sesuai yang } \\
\text { diharapkan }\end{array}$ & Valid \\
\hline 6 & $\begin{array}{c}\text { Penguji melakukan monitoring } \\
\text { kendaraan secara real time melalu } \\
\text { aplikasi viewer }\end{array}$ & $\begin{array}{l}\text { Posisi dari setiap kendaraan dapat } \\
\text { dilihat secara live pada tampilan } \\
\text { peta Google Maps }\end{array}$ & $\begin{array}{l}\text { Sesuai yang } \\
\text { diharapkan }\end{array}$ & Valid \\
\hline 7 & $\begin{array}{l}\text { Penguji melakukan verifikasi } \\
\text { melalui aplikasi viewer tanpa } \\
\text { QRCode }\end{array}$ & $\begin{array}{l}\text { Pengiriman terverifikasi tanpa } \\
\text { QRCode }\end{array}$ & $\begin{array}{l}\text { Sesuai yang } \\
\text { diharapkan }\end{array}$ & Valid \\
\hline 8 & $\begin{array}{l}\text { Penguji mencoba menggunakan } \\
\text { fitur auto-reconnect saat koneksi } \\
\text { database terputus karena sinyal } \\
\text { internet yang tidak memadai }\end{array}$ & $\begin{array}{l}\text { Sistem melakukan auto-reconnect } \\
\text { dan dapat berjalan normal kembali }\end{array}$ & $\begin{array}{l}\text { Sesuai yang } \\
\text { diharapkan }\end{array}$ & Valid \\
\hline
\end{tabular}

Pengujian sistem dilakukan untuk menguji fungsi yang telah dibuat dalam prototype sistem monitoring kendaraan. Pengujian sistem yang dilakukan menggunakan metode blackbox testing. Pengujian dilakukan menggunakan perangkat Android Xiaomi Redmi 3 Pro dengan Sistem Operasi Android 5.1.1. Blackbox Testing dilakukan untuk mengetahui bahwa semua fungsi dan fitur yang ada di dalam sistem berjalan sesuai dengan harapan.

58 Ramos Somya
Pengujian dilakukan dengan cara mencoba semua fungsi yang telah dibuat, kemudian membandingkan hasil pengujian dengan hasil yang diharapkan. Hasil blackbox testing dapat dilihat pada Tabel 1.

Hasil blackbox testing pada Tabel 1 menunjukkan bahwa status dari setiap fungsi adalah valid. Berdasarkan hasil yang didapat, 
maka dapat disimpulkan bahwa sistem yang dibuat berjalan dengan baik dan sesuai yang diharapkan.

Usability Testing dilakukan untuk mengetahui apakah sistem telah memenuhi proses bisnis dan kebutuhan yang ada pada proses tracking pengiriman barang (System Usability). Hasil usability testing pada sistem ini diketahui dengan menggunakan kuesioner sejumlah 8 pertanyaan positif [14] yang terdapat pada Tabel 2.

Tabel 2. Daftar Pertanyaan Usability Testing

\begin{tabular}{lllllll}
\hline No & \multicolumn{5}{c}{ Daftar Pertanyaan Skala } & \multicolumn{5}{c}{ Penilaian } \\
\hline 1 & $\begin{array}{l}\text { Secara keseluruhan, sistem } \\
\text { mudah digunakan }\end{array}$ & 1 & 2 & 3 & 4 & 5 \\
2 & $\begin{array}{l}\text { Fungsi-fungsi sistem sudah } \\
\text { sesuai dengan yang diharapkan }\end{array}$ & 1 & 2 & 3 & 4 & 5 \\
3 & $\begin{array}{l}\text { Sistem bersifat user friendly, } \\
\text { usertidak kesulitan dalam } \\
\text { penggunaan dan mudah untuk } \\
\text { belajar menggunakan sistem }\end{array}$ & 2 & 3 & 4 & 5 \\
4 & $\begin{array}{l}\text { Sistem tracking dapat digunakan } \\
\text { untuk mengakomodasi kebutuhan } \\
\text { tracking kendaraan }\end{array}$ & 1 & 2 & 3 & 4 & 5 \\
5 & $\begin{array}{l}\text { Sistem yang dibuat dapat } \\
\text { menggantikan sistem tracking } \\
\text { terdahulu }\end{array}$ & 2 & 3 & 4 & 5 \\
6 & $\begin{array}{l}\text { Fungsi tambahan seperti live } \\
\text { reporting dan verifikasi sangat } \\
\text { membantu dalam proses } \\
\text { pengiriman barang produksi }\end{array}$ & 2 & 3 & 4 & 5 \\
7 & $\begin{array}{l}\text { Sistem dapat dikembangkan lebih } \\
\text { jauh untuk mengakomodasi } \\
\text { kebutuhan lain dalam proses } \\
\text { pengiriman barang } \\
\text { Aplikasi yang dibuat tidak terasa } \\
\text { berat saat dijalankan dalam } \\
\text { perangkat Android }\end{array}$ & 2 & 3 & 4 & 5 \\
\hline
\end{tabular}

Kuesioner dilakukan saat mempresentasikan hasil akhir sistem. Responden dari kuesioner usability testing terdiri dari 6 orang staff MIS yang merupakan pengembang sistem dan aplikasi di PT. Pura. Hasil kuesioner diperlihatkan pada Gambar 9.

\section{Hasil Kuesioner System Usability}

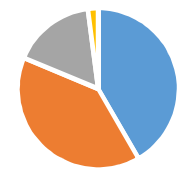

$$
\begin{aligned}
& \text { - Sangat Setuju - Setuju } \\
& \text { - Netral } \\
& \text { - Sangat Tidak Setuju }
\end{aligned}
$$

Gambar 9. Hasil Kuesioner System Usability

Berdasarkan hasil dari kuesioner, kemudian dilakukan perhitungan hasil dengan Skala Likert. Skala Likert adalah skala yang digunakan untuk mengukur persepsi, pendapat seseorang atau kelompok, dalam hal ini konteksnya adalah sistem monitoring kendaraan yang telah dibuat [15]. Perhitungan menggunakan bobot nilai Skala Likert dapat dilihat pada Tabel 3 dan hasilnya pada Tabel 4.

Hasil akhir dari Skala Likert dihitung dengan cara mengalikan jumlah setiap kategori jawaban dengan bobot nilainya [15]. Total nilai didapatkan dengan menjumlahkan setiap hasil perkalian sebelumnya. Pada Tabel 5 didapatkan hasil akhir nilai dari kuesioner yang dilakukan adalah 202.

Tabel 3. Bobot Nilai Skala Likert

\begin{tabular}{lc}
\hline \multicolumn{1}{c}{ Jawaban } & Bobot Nilai \\
\hline SS (Sangat Setuju) & 5 \\
S (Setuju) & 4 \\
N (Netral) & 3 \\
TS (Tidak Setuju) & 2 \\
STS (Sangat Tidak Setuju) & 1 \\
\hline
\end{tabular}

Kemudian untuk mengetahui persentase kepuasan mengenai sistem yang dibuat digunakan rumus \% Kepuasan. \% Kepuasan dihitung dengan cara membagi total nilai dengan $\mathrm{Y} * 100$, dengan $\mathrm{Y}=5 *$ total responden * total pertanyaan yang diajukan. Hasil yang didapat dengan menggunakan rumus \% Kepuasan dengan total responden $=6$ dan total pertanyaan $=8$ adalah:

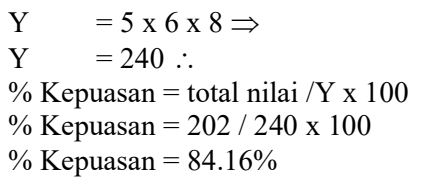

Tabel 5. Perhitungan Hasil Kuesioner menggunakan Bobot Nilai Skala Likert

\begin{tabular}{lcc}
\multicolumn{1}{c}{ Jawaban } & Jumlah & Total Nilai \\
\hline SS (Sangat Setuju) & 20 & 100 \\
S (Setuju) & 19 & 76 \\
N (Netral) & 8 & 24 \\
TS (Tidak Setuju) & 1 & 2 \\
STS (Sangat Tidak Setuju) & 0 & 0 \\
& Total & $\mathbf{2 0 2}$ \\
\hline
\end{tabular}

Perhitungan kepuasan kemudian dilakukan dengan mencocokkan hasil yang didapat dari rumus \% Kepuasan dengan tabel persentase pada Skala Likert. Tabel 5 menunjukkan tabel persentase yang digunakan untuk mengkategorikan skala kepuasan berdasarkan nilai yang didapat.

Tabel 5. Tabel Persentase Kategori Nilai Skala Likert

\begin{tabular}{cl}
\hline \% Kepuasan & \multicolumn{1}{c}{ Keterangan } \\
\hline $0 \%-19.99 \%$ & Sangat Buruk \\
$20 \%-39.99 \%$ & Kurang Baik \\
$40 \%-59.99 \%$ & Cukup \\
$60 \%-79.99 \%$ & Baik \\
$80 \%-100 \%$ & Sangat Baik \\
\hline
\end{tabular}

Berdasarkan semua perhitungan dengan Skala Likert didapatkan kesimpulan bahwa sistem yang dibuat sudah memenuhi keinginan dari responden. Kesimpulan ini diambil dari nilai \% Kepuasan yang mencapai $84.16 \%$ dan dicocokkan menggunakan nilai persentase pada Tabel 4 yang mengkategorikan nilai yang didapat dalam kategori sangat baik [15]. Sistem yang dibuat juga mendapatkan beberapa masukan seperti peningkatan informasi yang diberikan oleh aplikasi viewer, seperti estimasi waktu dan jarak kendaraan akan mencapai tujuan. Selain itu aplikasi tracker juga diberikan masukan untuk dapat memantau kegiatan kendaraan selain posisinya. Hal ini meliputi berapa lama kendaraan berhenti di satu tempat dan memberikan laporan jika kendaraan melenceng jauh dari rute yang seharusnya. 


\section{KESIMPULAN}

Berdasarkan penelitian yang dilakukan, didapatkan kesimpulan yaitu untuk membuat sebuah sistem monitoring kendaraan yang dapat diakses oleh unit produksi PT. Pura secara langsung adalah dengan membuat sistem monitoring kendaraan yang diimplementasikan ke dalam 2 aplikasi mobile berbasis Android. Aplikasi pertama adalah aplikasi yang dipakai driver kendaraan untuk keperluan tracking dan reporting, sedangkan aplikasi kedua adalah aplikasi monitoring dan verifikasi yang dipakai oleh administrator (dalam hal ini adalah perwakilan unit yang sedang menggunakan jasa transportasi PT. Pura.

Sistem monitoring kendaraan yang dibuat pada penelitian ini dapat memberikan laporan data lokasi kendaraan secara real time dan dapat diakses dengan cepat dan akurat saat dibutuhkan. Hal ini dapat dicapai dari penggunaan real time database yang diintegrasikan dengan sistem monitoring. Prototype sistem monitoring kendaraan dalam penelitian ini juga dapat digunakan untuk menggantikan sistem GPS tracker yang lama. Beberapa pertimbangan untuk menggunakan sistem yang baru adalah adanya fitur real time yang tidak mengharuskan mengirim SMS hanya untuk mendapat data lokasi setiap kendaraan. Selain itu sistem monitoring yang baru juga memiliki sistem pelaporan dan verifikasi barang yang terintegrasi, jadi tidak sebatas untuk keperluan tracking saja. Biaya operasional yang dikeluarkan juga akan lebih sedikit karena tidak memerlukan pembelian pulsa SMS dan menyewa alat GPS tracker dengan biaya bulanan, namun cukup membeli kartu SIM penyedia akses internet.

\section{DAFTAR PUSTAKA}

[1] Pura Group. "Creating Value Through Innovation." Internet: http://id.puragroup.com, May 25, 2017 [Feb. 05, 2018].

[2] R. Radifan. "Perancangan dan Pembuatan Sistem Informasi Lokasi Friend Finder Berbasis GPS pada Sistem Operasi Android”. Skripsi, Teknik Informatika Institut Teknologi Sepuluh November Surabaya, 2010.

[3] D. Alfikri. "Aplikasi Auto-Reporting Position Tracking Berbasis Android Untuk Mengetahui Posisi Device Sebagai Sarana Monitoring Posisi Karyawan di PT Telkom Indonesia Kota Malang". Skripsi, Teknik Informatika Universitas Muhammadiyah Malang, 2012.

[4] R. Abbott, H. Garcia-Molina. "What is a Real-Time Database System?". Abstracts of the Fourth Workshop on Real-Time Operating systems, IEEE, 1987, pp. 134-138.

[5] Firdausillah, Fahri, E.Y. Hidayat, I.N. Dewi. "NoSQL: Latar Belakang, Konsep, dan Kritik." Semantik (2012), Semarang.

[6] Apache Foundation. "Apache CouchDB." Internet: https://wiki.apache.org/couchdb/, Jan. 17, 2017 [Feb. 05, 2018].

[7] C. Anderson, J. Lehnardt, dan N. Slater. (2013). CouchDB: The Definitive Guide. O'Reilly Media.

[8] Lightcouch Guide. "Couch Guide." Internet: http://www.lightcouch.org/docs.html, May 25, 2017 [Feb. 05, 2018]

[9] Google. "Contribute to Google Maps and Earn Points." Internet:

https://support.google.com/maps/answer/6304221, May 10, 2017 [Feb. 05, 2018].

[10] A. Kindarto. (2008). Asyik Berinternet dengan Beragam Layanan Google. Yogyakarta: Andi.

[11] Z. Hasibuan. (2007). Metodologi Penelitian Pada Bidang Ilmu Komputer Dan Teknologi Informasi. Depok.

[12] R.S. Pressman. (1997). Rekayasa Perangkat Lunak Edisi ke-2. LN Harnaningrum, penerjemah: Yogyakarta: Andi.

[13] J. S. Dumas. (1999). A Practical Guide to Usability Testing. Intellect Books.

[14] J. R. Lewis. "IBM Computer Usability Satisfaction Questionnaires: Psychometric Evaluation and Instructions for Use," in International Journal of HumanComputer Interaction, 1995, pp. 57-78.

[15] H. Sarjono. "Sekilas Tentang Skala Likert." Internet: https://sbm.binus.ac.id/2015/06/26/sekilas-tentangskala-likert/, June 26, 2015 [Jul. 28, 2018]. 